\title{
Response of Soybean to Sulphur and Boron Nutrition in Northern Karnataka, India
}

\author{
S. Ravi ${ }^{1 *}$, R.L. Jadhav ${ }^{2}$ and Sidramappa ${ }^{3}$ \\ ${ }^{1}$ Deaprtment of Soil Science and Agricultural Chemistry, KVK, Bidar, UAS, Raichur, \\ Karnataka, India \\ ${ }^{2}$ Department of Agronomy, KVK, Bidar, UAS, Raichur, Karnataka, India \\ ${ }^{3}$ Department of Genetics and Plant Breeding, ARS, Bidar, Karnataka, India \\ *Corresponding author
}

\begin{tabular}{|c|c|}
\hline & A B S T R A C T \\
\hline & $\begin{array}{l}\text { This study is carried out to assess the sulphur and boron nutrient dynamics in soil and its } \\
\text { effect on seed yield of soybean under rainfed situation in northern Karnataka. An } \\
\text { exneriment was conducted during Kharif } 2014 \text { and } 2015 \text { t A Aricultural Research Station }\end{array}$ \\
\hline & Janwada, Bidar, comes under University of Agricultural Sciences, Raichur, Karnataka, \\
\hline $\begin{array}{l}\text { Seed yield, Uptake, } \\
\text { Nitrogen, Sulphur, } \\
\text { Boron, Soybean. }\end{array}$ & $\begin{array}{l}\text { India. Application of recommended dose of fertilizer }+12 \mathrm{~kg} \mathrm{ZnSO} / \mathrm{ha}+30 \mathrm{~kg} \\
\mathrm{Sulphur} / \mathrm{ha}+1.0 \mathrm{~kg} \text { Boron/ha recorded significantly }(\mathrm{p}=0.05) \text { higher seed yield }(22.7 \mathrm{q} / \mathrm{ha}) \\
\text { and which was onpar with the application of recommended dose of fertilizer }+12 \mathrm{~kg} \\
\mathrm{ZnSO}_{4} / \mathrm{ha}+30 \mathrm{~kg} \text { Sulphur } / \mathrm{ha}+1.5 \mathrm{~kg} \text { Boron } / \mathrm{ha}(21.5 \mathrm{q} / \mathrm{ha}) \text { compared to other treatments. }\end{array}$ \\
\hline Article Info & Further, significantly $(\mathrm{p}=0.05)$ higher uptake of nitrogen $(163.0 \mathrm{~kg} / \mathrm{ha})$, phosphorus $(18.5$ \\
\hline $\begin{array}{l}\text { Accepted: } \\
\text { 26 October } 2017 \\
\text { Available Online: } \\
10 \text { December } 2017\end{array}$ & $\begin{array}{l}\mathrm{kg} / \mathrm{ha}) \text {, potassium }(74.61 \mathrm{~kg} / \mathrm{ha}) \text {, sulphur }(22.16 \mathrm{~kg} / \mathrm{ha}) \text { and boron }(0.14 \mathrm{~kg} / \mathrm{ha}) \text { were } \\
\text { recorded in the treatment with the application of recommended dose of fertilizer }+12 \mathrm{~kg} \\
\mathrm{ZnSO}_{4} / \mathrm{ha}+30 \mathrm{~kg} \text { Sulphur } / \mathrm{ha}+1.0 \mathrm{~kg} \text { Boron } / \mathrm{ha} \text { and which was onpar with the application } \\
\text { of recommended dose of fertilizer }+12 \mathrm{~kg} \mathrm{ZnSO} / \mathrm{ha}+30 \mathrm{~kg} \text { Sulphur } / \mathrm{ha}+1.5 \mathrm{~kg} \text { Boron } / \mathrm{ha} \\
(160.5,16.48,73.19,20.12 \text { and } 0.12 \mathrm{~kg} / \mathrm{ha} \text {, respectively. Application of recommended }\end{array}$ \\
\hline & $\begin{array}{l}\text { dose of fertilizer }(40: 80: 25 \mathrm{~kg} \mathrm{NPK} / \mathrm{ha})+12 \mathrm{~kg} \mathrm{ZnSO} / \mathrm{ha}+30 \mathrm{~kg} \text { Sulphur} / \mathrm{ha}+1.0 \mathrm{~kg} \\
\text { Boron/ha was increases the seed yield of soybean and uptake of nutrients under northern } \\
\text { Karnataka. }\end{array}$ \\
\hline
\end{tabular}

\section{Introduction}

Soybean (Glycine $\max$ (L.) Merrill) is recognized as "Golden Bean" due to its high nutritional value such as high quality protein (40-45\%), oil (18-20\%), mineral nutrients like calcium, iron and glycine. Apart from these, it is a good source of isoflavone which helps in preventing heart disease, cancer and HIVs. In India, the area under soybean cultivation was $10.18 \mathrm{~m}$ ha and the production was $12.28 \mathrm{~m} \mathrm{t}$ with productivity level of $1.21 \mathrm{t}$ per ha, though the crop has potential productivity of nearly $2,500-3,000 \mathrm{~kg}$ per ha (1). Sulphur is involved in synthesis of fatty acid and also increased protein quality through the synthesis of certain sulphur containing amino acid such as cystine, cystein and methionine (2). Boron deficiency occurs in highly leached sandy soils, acidic soils and soils low in organic matter and it plays an important role in nodulation, flowering, 
pollen germination, fruiting, seed setting and synthesis of protein and oil (3). Northern Karnataka, India is dominated by medium to deep black and red lateritic soils and these soils are poor in soil fertility due to deficiency of secondary and micronutrients. Soybean is one of the important oil seed crop and it is being grown in an area of 95,000 ha with a production of 33,250 thousand tonnes with an average productivity of $725 \mathrm{~kg} / \mathrm{ha}$.

Since, the yields are low as compared to state average $(950 \mathrm{Kg} / \mathrm{ha}$. Intensive cropping, indiscriminate use of fertilizers and limited use of organic matter are the reasons for occurrence of sulphur and boron deficiency in the region which limits soybean yield. However, very meagre information is available on response of soybean to sulphur and boron nutrition. Hence a field experiment was conducted to investigate the effect of sulphur and boron nutrition on soybean yield in Northern Karnataka.

\section{Materials and Methods}

\section{Background of the study}

An experiment was carried out during Kharif 2014 and 2015 at Agricultural Research Station, Janwada, Bidar, University of Agricultural Sciences, Raichur, Karnataka, India.

The soil of the experimental field was clay soil, slightly saline in $\mathrm{pH}$ (8.32), medium in organic carbon $(0.53 \%)$, available nitrogen (285.0 kg N/ha), phosphorus ( $30 \mathrm{~kg} \mathrm{P}_{2} \mathrm{O}_{5} / \mathrm{ha}$ ), potassium (416 kg $\mathrm{K}_{2} \mathrm{O} / \mathrm{ha}$ ), sulphur (8.3 $\mathrm{ppm})$ and boron $(0.46 \mathrm{ppm})$.

\section{Treatments details}

This experiment was comprises of eight treatments viz., $\mathrm{T}_{1}$ : Absolute Control, $\mathrm{T}_{2}$ : RPP $(40: 85: 25 \mathrm{~kg} \mathrm{NPK}+12 \mathrm{~kg} \mathrm{ZnSO}+20 \mathrm{~kg}$ Sulphur/ha), $\mathrm{T}_{3}$ : RPP $+0.5 \mathrm{~kg}$ Boron/ha, $\mathrm{T}_{4}$ :
$\mathrm{RPP}+1.0 \mathrm{~kg}$ Boron/ha, $\mathrm{T}_{5}: \mathrm{RPP}+1.5 \mathrm{~kg}$ Boron/ha, $\mathrm{T}_{6}$ : Recd. NPK (40:85:25) $+12 \mathrm{~kg}$ $\mathrm{ZnSO}_{4}+30 \mathrm{~kg}$ Sulphur $+0.5 \mathrm{~kg}$ Boron/ha, $\mathrm{T}_{7}$ : Recd. NPK (40:85:25) + $12 \mathrm{~kg} \mathrm{ZnSO}+30 \mathrm{~kg}$ Sulphur $+1.0 \mathrm{~kg}$ Boron $/ \mathrm{ha}, \mathrm{T}_{8}$ : Recd. NPK $(40: 85: 25)+12 \mathrm{~kg} \mathrm{ZnSO}+30 \mathrm{~kg}$ Sulphur + $1.5 \mathrm{~kg}$ Boron/ha.

\section{Experimental details}

The experiment was laid out in randomized complete block design with three replications. Soybean variety JS 335 was grown at a row spacing of $45 \mathrm{~cm}$. Crop received recommended dose of nutrients @ 40:80:25: $\mathrm{kg} \mathrm{N}: \mathrm{P}_{2} \mathrm{O}_{5}: \mathrm{K}_{2} \mathrm{O}$ per ha through urea, diammonium phosphate and muriate of potash, respectively. Sulphur and boron were applied as per treatment details through gypsum (18 $\% \mathrm{~S})$ and borax (11\% B). Soybean seed were inoculated with Bradyrhizobium japonicum culture@5 g per kg seed. The rainfall received during kharif 2014 and 2015 was $800 \mathrm{~mm}$ and $950 \mathrm{~mm}$, respectively. Other crop management practices were performed as per recommended package of practices.

\section{Analysis of nutrients}

The plant samples were collected for recording dry matter production and estimation of nutrient concentration. The plant samples used for recording dry matter production at harvest were used for analyzing nutrients present in the plant. After recording the dry weight from each treatment the samples were powdered in a micro Willey mill.

The samples were analyzed for concentration of different nutrients ( $\mathrm{N}, \mathrm{P}$ and $\mathrm{K}$ ) present in the plant parts. Nitrogen Phosphorus and potassium content of stover was estimated by modified micro-Kjeldhal's method, Vanadomolybdo phosphoric acid yellow colour method and absorbance of the solution was recorded at $430 \mathrm{~nm}$ using 
spectrophotometer and flame photometer method, respectively (4). Similarly, Available nitrogen was determined by alkaline permanganate method as outlined by Subbiah and Asija (5). Available phosphorus was determined by Bray's method as outlined by Jackson (4). Available potassium was determined by neutral normal ammonium acetate solution using flame photometer as outlined by Jackson (4). The seed samples were digested in nitricperchloric acid to determine S and B. Sulphur was determined turbidimetrically (6) and boron by cramine method (7).

\section{Data collection and economics}

The observations on growth parameters/ attributes like plant height, branches per plant, pods per plant, and dry matter per plant was taken on five randomly selected plants from each treatment at harvest. Observation on seed index was taken and expressed as g per 100 seed. After harvest and threshing of crop, seed yield was recorded in net plot wise and converted to grain yield per hectare basis. The cost of inputs that were prevailing at the time of their use was considered for working out the economics of various treatments. Net return per hectare was calculated by deducting the cost of cultivation from gross returns per hectare, gross returns was calculated by using the total income obtained from grain and straw yield of rice and the benefit cost ratio was worked out as follows.

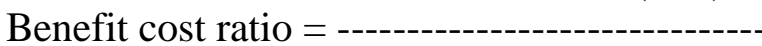 \\ Cost of cultivation ( $/$ ha)}

\section{Data analysis}

MSTAT was used for statistical analysis of data and means were separated using critical difference $(C D)$ at $p=0.05$. The data on weeds were transformed by square root transformation before being subjected to ANOVA (8).

\section{Results and Discussion}

\section{Effect of sulphur and boron nutrition on} growth parameters of soybean

Growth parameters like plant height and number of branches per plant showed a significant variation with different sulphur and boron levels along with recommended dose of fertilizer application. Application of recommended dose of fertilizer $+12 \mathrm{~kg}$ $\mathrm{ZnSO}_{4} / \mathrm{ha}+30 \mathrm{~kg}$ Sulphur/ha $+1.0 \mathrm{~kg}$ Boron/ha recorded significantly $(\mathrm{p}=0.05)$ taller plants $(74 \mathrm{~cm})$ and which was onpar with the application of recommended dose of fertilizer $+12 \mathrm{~kg} \mathrm{ZnSO} / \mathrm{ha}+30 \mathrm{~kg}$ Sulphur/ha +1.5 kg Boron/ha $(69.0 \mathrm{~cm})$ compared to other treatments. Further, significantly $(\mathrm{p}=0.05)$ maximum branches (6.10) were recorded in the treatment with the application of recommended dose of fertilizer $+12 \mathrm{~kg} \mathrm{ZnSO} / \mathrm{ha}+30 \mathrm{~kg}$ Sulphur$/ \mathrm{ha}+1.0 \mathrm{~kg}$ Boron/ha and which was onpar with the application of recommended dose of fertilizer $+12 \mathrm{~kg} \mathrm{ZnSO} / \mathrm{ha}+30 \mathrm{~kg}$ Sulphur/ha $+1.5 \mathrm{~kg}$ Boron/ha (5.05). This might be due to high accumulation of net photosynthates. The results obtained are consistent with findings reported by Meena et al., (9). However, least plant and branches were noticed in absolute control treatment (Table 1).

\section{Effect of sulphur and boron nutrition on yield and yield parameters of soybean}

Yield attributes like number of pods per plant, seed index, haulm and seed yield showed a significant variation for different sulphur and boron levels along with recommended dose of fertilizer application (Table 1). Results, revealed that, application of $12 \mathrm{~kg} \mathrm{ZnSO}_{4} / \mathrm{ha}$ $+30 \mathrm{~kg} \mathrm{Sulphur} / \mathrm{ha}+1.0 \mathrm{~kg}$ Boron/ha along with recommended dose of fertilizer recorded significantly $(\mathrm{p}=0.05)$ higher pods per plant (94) and seed yield (22.7 q/ha) and which was on par with the application of recommended dose of fertilizer $+12 \mathrm{~kg} \mathrm{ZnSO} / \mathrm{ha}+30 \mathrm{~kg}$ 
Sulphur/ha $+1.5 \mathrm{~kg}$ Boron/ha (85.0 and 21.5 $\mathrm{q} / \mathrm{ha}$, respectively) compared to other treatments. Further, significantly $(\mathrm{p}=0.05)$ lower pods per plant and seed yield were recorded in the treatment absolute control.

This might be due to the favourable role of boron in nodulation and seed formation process. The results are in consistent with the findings of Saxena and Nainwal (10) who reported that seed and haulm yield increased significantly with incremental dose of sulphur and boron application.

\section{Effect of sulphur and boron nutrition on nutrient uptake of soybean}

Nitrogen, phosphorus, potassium, sulphur and boron uptake by soybean was significantly $(\mathrm{p}=0.05)$ increased with different rate of application of sulphur and boron level (Table 2).

Maximum uptake of nitrogen $(163.0 \mathrm{~kg} / \mathrm{ha})$, phosphorus (18.5 kg/ha) and potassium (74.61 $\mathrm{kg} / \mathrm{ha}$ ) by soybean was observed in the treatment with the application of recommended dose of fertilizer $+12 \mathrm{~kg}$ $\mathrm{ZnSO}_{4} / \mathrm{ha}+30 \mathrm{~kg}$ Sulphur/ha $+1.0 \mathrm{~kg}$ Boron/ha (22.16 kg/ha) and which was onpar with the application of recommended dose of fertilizer $+12 \mathrm{~kg} \mathrm{ZnSO} / \mathrm{ha}+30 \mathrm{~kg}$ Sulphur/ha $+1.5 \mathrm{~kg}$ Boron/ha $(160.5,16.48$ and $73.19 \mathrm{~kg} / \mathrm{ha}$, respectively) compared to other treatments.

The control treatment recorded the lowest uptake of nitrogen, phosphorus and potassium.

Table.1 Effect of sulphur and boron nutrition on growth, yield and yield attributes of soybean (Mean of 2014 and 2015)

\begin{tabular}{|c|c|c|c|c|c|c|}
\hline Treatments & $\begin{array}{c}\text { Plant } \\
\text { height } \\
(\mathrm{cm})\end{array}$ & $\begin{array}{c}\text { No. of } \\
\text { branches/ } \\
\text { plant }\end{array}$ & $\begin{array}{c}\text { No. of } \\
\text { pods/pla } \\
\text { nt }\end{array}$ & $\begin{array}{l}100 \text { Seed } \\
\text { weight } \\
\text { (g) }\end{array}$ & $\begin{array}{c}\text { Haulm } \\
\text { yield } \\
(\mathrm{kg} / \mathrm{ha})\end{array}$ & $\begin{array}{l}\text { Seed } \\
\text { yield } \\
(\mathbf{q} / \mathbf{h a})\end{array}$ \\
\hline $\mathrm{T}_{1}$ : Absolute control & 44.7 & 2.60 & 45.0 & 9.72 & 1128 & 9.24 \\
\hline $\begin{array}{l}\mathrm{T}_{2}: \mathrm{RPP}(40: 80: 25 \mathrm{~kg} \mathrm{NPK} / \mathrm{ha}) \\
+12 \mathrm{~kg} \mathrm{ZnSO} / \mathrm{ha}+20 \mathrm{~kg} \\
\text { Sulphur/ha) }\end{array}$ & 58.4 & 3.60 & 68.5 & 10.5 & 2356 & 18.4 \\
\hline $\mathrm{T}_{3}: \mathrm{RPP}+0.5 \mathrm{~kg}$ Boron/ha & 62.4 & 3.60 & 69.0 & 12.0 & 2402 & 19.2 \\
\hline $\mathrm{T}_{4}: \mathrm{RPP}+1.0 \mathrm{~kg}$ Boron $/ \mathrm{ha}$ & 66.9 & 4.60 & 82.5 & 13.0 & 2772 & 20.9 \\
\hline $\mathrm{T}_{5}: \mathrm{RPP}+1.5 \mathrm{~kg}$ Boron/ha & 61.9 & 3.95 & 72.5 & 12.4 & 2555 & 19.4 \\
\hline $\begin{array}{l}\mathrm{T}_{6}: \mathrm{RDF}(40: 80: 25 \mathrm{~kg} \mathrm{NPK} / \mathrm{ha}) \\
+12 \mathrm{~kg} \mathrm{ZnSO} / \mathrm{ha}+30 \mathrm{~kg} \\
\text { Sulphur/ha }+0.5 \mathrm{~kg} \text { Boron } / \mathrm{ha}\end{array}$ & 63.3 & 4.40 & 78.5 & 13.7 & 2615 & 20.3 \\
\hline $\begin{array}{l}\mathrm{T}_{7}: \mathrm{RDF}+12 \mathrm{~kg} \mathrm{ZnSO} / / \mathrm{ha}+30 \\
\mathrm{~kg} \text { Sulphur/ha }+1.0 \mathrm{~kg} \text { Boron/ha }\end{array}$ & 74.0 & 6.10 & 94.0 & 14.6 & 3054 & 22.7 \\
\hline $\begin{array}{l}\mathrm{T}_{8}: \mathrm{RDF}+12 \mathrm{~kg} \mathrm{ZnSO} / \mathrm{ha}+30 \\
\mathrm{~kg} \text { Sulphur/ha }+1.5 \mathrm{~kg} \text { Boron/ha }\end{array}$ & 69.0 & 5.05 & 85.0 & 13.8 & 2823 & 21.5 \\
\hline C.D.(P=0.05) & 5.99 & 0.84 & 9.84 & 1.13 & 245.9 & 1.77 \\
\hline
\end{tabular}


Table.2 Effect of sulphur and boron nutrition on nutrient uptake of soybean (Mean of 2014 and 2015)

\begin{tabular}{|c|c|c|c|c|c|}
\hline \multirow{2}{*}{ Treatments } & \multicolumn{5}{|c|}{ Uptake of nutrients (kg/ha) } \\
\hline & Nitrogen & Phosphorus & Potassium & Sulphur & Boron \\
\hline $\mathrm{T}_{1}:$ Absolute control & 123.0 & 11.2 & 51.05 & 8.19 & 0.04 \\
\hline $\begin{array}{l}\mathrm{T}_{2}: \mathrm{RPP}(40: 80: 25 \mathrm{~kg} \mathrm{NPK} / \mathrm{ha}) \\
+12 \mathrm{~kg} \mathrm{ZnSO} / \mathrm{ha}+20 \mathrm{~kg} \\
\text { Sulphur/ha) }\end{array}$ & 135.0 & 13.89 & 63.67 & 13.15 & 0.07 \\
\hline $\mathrm{T}_{3}: \mathrm{RPP}+0.5 \mathrm{~kg}$ Boron $/ \mathrm{ha}$ & 139.0 & 13.87 & 64.05 & 15.23 & 0.08 \\
\hline $\mathrm{T}_{4}: \mathrm{RPP}+1.0 \mathrm{~kg}$ Boron $/ \mathrm{ha}$ & 155.0 & 15.37 & 70.10 & 17.98 & 0.11 \\
\hline $\mathrm{T}_{5}: \mathrm{RPP}+1.5 \mathrm{~kg}$ Boron $/ \mathrm{ha}$ & 143.5 & 14.30 & 67.21 & 16.17 & 0.09 \\
\hline $\begin{array}{l}\mathrm{T}_{6}: \operatorname{RDF}(40: 80: 25 \mathrm{~kg} \mathrm{NPK} / \mathrm{ha}) \\
+12 \mathrm{~kg} \mathrm{ZnSO} / \mathrm{ha}+30 \mathrm{~kg} \\
\text { Sulphur/ha }+0.5 \mathrm{~kg} \text { Boron/ha }\end{array}$ & 149.0 & 15.24 & 70.16 & 19.21 & 0.10 \\
\hline $\begin{array}{l}\mathrm{T}_{7}: \mathrm{RDF}+12 \mathrm{~kg} \mathrm{ZnSO} / \mathrm{ha}+ \\
30 \mathrm{~kg} \text { Sulphur} / \mathrm{ha}+1.0 \mathrm{~kg} \\
\text { Boron } / \mathrm{ha}\end{array}$ & 163.0 & 18.50 & 74.61 & 22.16 & 0.14 \\
\hline $\begin{array}{l}\mathrm{T}_{8}: \mathrm{RDF}+12 \mathrm{~kg} \mathrm{ZnSO} / \mathrm{ha}+ \\
30 \mathrm{~kg} \text { Sulphur} / \mathrm{ha}+1.5 \mathrm{~kg} \\
\text { Boron/ha }\end{array}$ & 160.5 & 16.48 & 73.19 & 20.12 & 0.12 \\
\hline C.D. $(P=0.05)$ & 7.79 & 3.60 & 4.31 & 2.74 & 0.02 \\
\hline
\end{tabular}

Table.3 Economics of soybean as influenced by the application of sulphur and boron (Mean of 2014 and 2015)

\begin{tabular}{|c|c|c|c|c|}
\hline Treatment & $\begin{array}{l}\text { Cost of } \\
\text { cultivation } \\
\quad(\text { Rs. })\end{array}$ & $\begin{array}{l}\text { Gross } \\
\text { Returns } \\
(\text { Rs. })\end{array}$ & $\begin{array}{c}\text { Net } \\
\text { Returns } \\
\text { (Rs.) }\end{array}$ & $\begin{array}{l}\text { B:C } \\
\text { ratio }\end{array}$ \\
\hline $\mathrm{T}_{1}$ : Absolute control & 26496 & 38088 & 11592 & 1.44 \\
\hline $\begin{array}{l}\mathrm{T}_{2}: \mathrm{RPP}(40: 80: 25 \mathrm{~kg} \mathrm{NPK} / \mathrm{ha})+12 \\
\left.\mathrm{~kg} \mathrm{ZnSO}_{4} / \mathrm{ha}+20 \mathrm{~kg} \mathrm{Sulphur} / \mathrm{ha}\right)\end{array}$ & 30864 & 76076 & 45212 & 2.46 \\
\hline $\mathrm{T}_{3}: \mathrm{RPP}+0.5 \mathrm{~kg}$ Boron $/ \mathrm{ha}$ & 31888 & 79522 & 47634 & 2.49 \\
\hline $\mathrm{T}_{4}: \mathrm{RPP}+1.0 \mathrm{~kg}$ Boron/ha & 30842 & 86572 & 55730 & 2.81 \\
\hline $\mathrm{T}_{5}: \mathrm{RPP}+1.5 \mathrm{~kg}$ Boron $/ \mathrm{ha}$ & 30837 & 80355 & 49518 & 2.61 \\
\hline $\begin{array}{l}\mathrm{T}_{6}: \mathrm{RDF}(40: 80: 25 \mathrm{~kg} \text { NPK/ha })+12 \\
\mathrm{~kg} \mathrm{ZnSO} / \mathrm{ha}+30 \mathrm{~kg} \text { Sulphur} / \mathrm{ha}+ \\
0.5 \mathrm{~kg} \text { Boron } / \mathrm{ha}\end{array}$ & 32458 & 84135 & 51677 & 2.59 \\
\hline $\begin{array}{l}\mathrm{T}_{7}: \mathrm{RDF}+12 \mathrm{~kg} \mathrm{ZnSO} / \mathrm{ha}+30 \mathrm{~kg} \\
\text { Sulphur} / \mathrm{ha}+1.0 \mathrm{~kg} \text { Boron } / \mathrm{ha}\end{array}$ & 32466 & 94014 & 61548 & 2.90 \\
\hline $\begin{array}{l}\mathrm{T}_{8}: \mathrm{RDF}+12 \mathrm{~kg} \mathrm{ZnSO} / \mathrm{ha}+30 \mathrm{~kg} \\
\text { Sulphur/ha }+1.5 \mathrm{~kg} \text { Boron } / \mathrm{ha}\end{array}$ & 33471 & 88903 & 55432 & 2.66 \\
\hline C.D. $(P=0.05)$ & $\mathbf{N S}$ & NS & 6119 & 0.25 \\
\hline
\end{tabular}


Similarly, Sulphur uptake increased with increasing levels of sulphur; maximum being associated with the application of recommended dose of fertilizer $+12 \mathrm{~kg}$ $\mathrm{ZnSO}_{4} / \mathrm{ha}+30 \mathrm{~kg}$ Sulphur/ha $+1.0 \mathrm{~kg}$ Boron/ha (22.16 kg/ha) and which was onpar with the application of recommended dose of fertilizer $+12 \mathrm{~kg} \mathrm{ZnSO}_{4} / \mathrm{ha}+30 \mathrm{~kg}$ Sulphur/ha $+1.5 \mathrm{~kg}$ Boron/ha $(20.12 \mathrm{~kg} / \mathrm{ha})$ compared to other treatments. The control treatment recorded the lowest uptake of sulphur. The above results revealed that sulphur doses increased sulphur uptake due to high sulphur content and grain yield. Similar findings are also reported by Ganeshamurthy (11) who reported that application of sulphur significantly increased the sulphur uptake in soybean. The highest boron uptake was achieved by application of recommended dose of fertilizer $+12 \mathrm{~kg} \mathrm{ZnSO} / \mathrm{ha}+30 \mathrm{~kg}$ Sulphur/ha $+1.0 \mathrm{~kg}$ Boron $/ \mathrm{ha}(0.14 \mathrm{~kg} / \mathrm{ha})$ and which was closely followed by the application of recommended dose of fertilizer $+12 \mathrm{~kg}$ $\mathrm{ZnSO}_{4} / \mathrm{ha}+30 \mathrm{~kg}$ Sulphur$/ \mathrm{ha}+1.5 \mathrm{~kg}$ Boron/ha $(0.12 \mathrm{~kg} / \mathrm{ha})$ compared to other treatments. The lowest boron uptake was observed with control.

\section{Economics of soybean as influenced by the application of sulphur and boron}

Economic evaluation (Table 3) revealed that, the maximum net returns ( $61548 / \mathrm{ha}$ ) and benefit cost ratio (2.90) were obtained with the application of recommended dose of fertilizer $+12 \mathrm{~kg} \mathrm{ZnSO} / \mathrm{ha}+30 \mathrm{~kg}$ Sulphur/ha $+1.0 \mathrm{~kg}$ Boron/ha and which was closely followed by the application of recommended package of practice $+1.0 \mathrm{~kg}$ Boron/ha ( $55730 /$ ha and 2.81, respectively) compared to other treatments. Further, least net returns and benefit cost ratio was observed in absolute control. These results are conformity with the findings of Singh, et al., (12) stated that, the maximum net returns ( $20,115 / \mathrm{ha})$ were obtained with $40 \mathrm{~kg} \mathrm{~S}$ per ha, which was significantly superior over control, but at par with $30 \mathrm{~kg} \mathrm{~S}$ per ha. Similarly, application of $2.0 \mathrm{~kg} \mathrm{~B}$ per ha recoded maximum net returns ( $19,591 / \mathrm{ha})$, which was significantly superior to $0.5 \mathrm{~kg} \mathrm{~B}$ per ha and control, but was on par with $1 \mathrm{~kg}$ and $1.5 \mathrm{~kg} \mathrm{~B}$ per ha. The highest $\mathrm{B}: \mathrm{C}$ ratio of 1.98 was recorded with the application of 30 $\mathrm{kg} \mathrm{S}$ per ha.

On the basis of results of two years experimentations, it may be concluded that, application of recommended dose of fertilizer + $12 \mathrm{~kg} \mathrm{ZnSO} / \mathrm{ha}+30 \mathrm{~kg}$ Sulphur/ha $+1.0 \mathrm{~kg}$ Boron/ha enhanced growth, yield and uptake of soybean and proved most economical in northern Karnataka.

\section{References}

1. Anonymous. 2012. Director's Report and Summary Tables of Experiments (2011- 2012), All India Coordinated Research Project on Soybean, Indore.

2. Havlin L J, Beaton D J, Tisdale L S and Nelson L W. 1999. Soil fertility and fertilizers. Prentice hall of India, 6th ed., pp 220-27 and 319-346.

3. Malewar G V, Kate S D, Waiker S L and Ismail S. 2001. Interaction effect of zinc and boron on yield, nutrient uptake and quality of mustard (Brassica juncia L.) on a typic Haplustert. Journal of Indian Society of Soil Science 49: 7635.

4. Jackson, M.L., 1967, Soil Chemical Analysis. Prentice Hall of India Pvt. Ltd., New Delhi, pp. 183-192.

5. Subbiah, B.V. and Asija, C.L., 1959, A rapid procedure for estimation of available nitrogen in soils. Curr. Sci., 25:259-260.

6. Page A L, Millar R H and keeney D R. 1989. Methods of Soil Analysis Part 2. American Society of Agronomy 
Madison, Wisconsin, USA, Pp. 152531.

7. Hatcher $\mathrm{J} T$ and Wilcox L V. 1950 Calorimetric determination of boron using caramine. Analytical Chemistry 22: 567-9.

8. Gomez, K.A. and A.A. Gomez, (1984). Statistical procedures for agricultural research (2 ed.). John wiley and sons, NewYork, 680p

9. Meena D S, Ram B and Tetarwal J P. 2011. Productivity, quality and profitability of soybean (Glycine max L.) as influenced by sulphur and boron nutrition. Soybean Research 9: 103-108.
10. Saxena S C and Nainwal R C. 2010. Effect of sulphur and boron nutrition on yield, yield attributes and economics of soybean. Soybean Research 8: 7-12.

11. Ganeshamurthy A N. 1996. Effect of sulphur application on seed and oil yield of Soybean. Journal of the Indian Society of Soil Science 44(2): 290-4.

12. Singh, A. K., Singh, C. S. and Yadava, J. P., 2013, Response of Soybean to Sulphur and Boron Nutrition in Acid Upland Soils of Jharkhand. Soybean Research 11(2): 27-34.

\section{How to cite this article:}

Ravi, S., R.L. Jadhav and Sidramappa. 2017. Response of Soybean to Sulphur and Boron Nutrition in Northern Karnataka. Int.J.Curr.Microbiol.App.Sci. 6(12): 3426-3432. doi: https://doi.org/10.20546/ijcmas.2017.612.398 